\title{
Chemical Composition of Straw as an Alternative Material to Wood Raw Material in Fibre Isolation
}

\section{Kemijski sastav slame kao alternative drvnoj sirovini za dobivanje vlakanaca}

\author{
Original scientific paper • Izvorni znanstveni rad \\ Received-prispjelo: 17. 12. 2014. \\ Accepted-prihvaćeno: 5. 5. 2016. \\ UDK: $630 * 88 ; 630 * 813.1$ \\ doi:10.5552/drind.2016.1446
}

\begin{abstract}
Wood is still the most widely used raw material for pulp and paper production in the world. However, due to the necessity to supply the paper industry with raw materials used in the extraction of cellulose fibres and the overexploitation of forests, new sources of primary pulp fibres had to be identified. The aim of this research is to highlight the important features of cereal crop residues and their utilization in the paper industry. As the chemical composition of plant materials is one of the most important indicators of how such materials can be used in paper production, the analysis of the chemical composition of straw with the highest grain production was performed. The straw, as a harvesting residue, is a fibre resource available from the annually renewable crops, produced abundantly in numerous regions all over the world. For the purpose of the research, wheat, triticale and barley straw were selected for the analysis. The analysis of carbohydrate, lignin and extraneous material (organic extractives and inorganic minerals) was performed in order to obtain the straw chemical composition. Based on the results of the chemical composition of all analysed straw, it was confirmed that straw, as an agricultural by-product, is rich in cellulosic fibres and, therefore, a valuable raw material for the paper industry. Out of all analysed straw, based on the results of their chemical composition, triticale straw is considered potentially the best source of alternative cellulose fibres.
\end{abstract}

Key words: straw, wheat, barley, triticale, chemical composition

SAŽETAK・Drvo je još uvijek najčešća sirovina za proizvodnju celuloze i papira u svijetu. Međutim, s obzirom na količinu sirovine za izdvajanje celuloznih vlakanaca potrebnih papirnoj industriji te na prekomjernu eksploataciju šuma, nužno je pronaći nove izvore primarnih celuloznih vlakanca. Cilj ovog istraživanja bio je istaknuti važnost slame koja je kao poljoprivredni ostatak prikladna sirovina za industriju papira. Kako je kemijski sastav biljnog materijala jedan od najvažnijih razloga njegove upotrebe u proizvodnji papira, određen je kemijski sastav slame žitarica s najvećim doprinosom zrna. Slama, kao ostatak nakon žetve, godišnje je obnovljiv izvor vlakanaca te je u mnogim regijama diljem svijeta dostupna u izobilju. Za ovo je istraživanje izabrana slama pšenice, pšenoraži $i$ ječma. Obavljena je kvantitativna analiza ugljikohidrata, lignina i ekstraktivnih tvari (organski ekstrakti i anorganski minerali) kako bi se odredio kemijski sastav slame žitarica. Na temelju kemijskog sastava svih analiziranih

\footnotetext{
${ }^{1}$ Author is a teaching assistant at the University of Zagreb, Faculty of Graphic Arts, Zagreb, Croatia. ${ }^{2}$ Author is an associate professor at the University of Zagreb, Faculty of Graphic Arts, Zagreb, Croatia. ${ }^{3}$ Author is an assistant professor at the University of Zagreb, Faculty of Forestry, Zagreb, Croatia.

Autorica je poslijedoktorandica Sveučilišta u Zagrebu, Grafički fakultet, Zagreb, Hrvatska. ${ }^{2}$ Autorica je izvanredna profesorica Sveučilišta u Zagrebu, Grafički fakultet, Zagreb, Hrvatska. ${ }^{3}$ Autor je docent Sveučilišta u Zagrebu, Šumarski fakultet, Zagreb, Hrvatska.
} 
slama potvrđeno je kako je slama kao poljoprivredni nusproizvod bogat izvor celuloznih vlakanaca, a time $i$ vrijedna sirovina za industriju papira. Od svih analiziranih uzoraka slama pšenoraži svojim se kemijskim sastavom nametnula kao najveći potencijalni izvor alternativnih celuloznih vlakanaca.

Ključne riječi: slama, pšenica, ječam, pšenoraž, kemijski sastav

\section{INTRODUCTION \\ 1. UVOD}

Cellulose fibres are a valuable raw material for the paper industry, which has been, in recent years, still one of the fastest growing industries (De Galembert, 2003; Valois et al., 2012). The availability of conventional and forest-based raw materials used in fibre isolation became limited due to the increasing demand for pulp and paper products. According to their origin, fibres can be divided into natural cellulose fibres and man-made (synthetic) ones. Since synthetic fibres are completely man made, the length of these fibres is also fully controlled by man (Lainio, 2010). Natural fibres are abundantly present in plants such as wood, grass, reeds, stalks and straw and the length of these fibres is an inherent limitation defined by the natural material they originate from. Wood has been the most widely used raw material for pulp and paper production in the world. As the demand for paper products is increasingly growing, identifying alternative sources of virgin cellulose fibres is of great importance, considering that different types of coniferous and deciduous trees became insufficient raw material for the paper production.

In recent years, non-wood fibres have been considered as a potential source of papermaking raw material. Non-wood fibres, as agricultural residues and annual plants, are low-cost raw materials and, therefore, interesting as sources of alternative fibres to wood cellulose fibres (Sirdach, 2010). The benefit of non-wood plants as fibre sources, with straw being a by-product in the process, is their fast annual growth. Therefore, these non-wood plants, and their straw, represent an annually renewable fibre resource available in abundant quantities in many regions all over the world. Nowadays, countries with a high use of agro residue based fibres are India and China (Jahan et al., 2009; Leponiemi, 2008; Chandra, 1998). In European countries such as Italy, Germany, France, Spain, Greece, Hungary and Croatia, agricultural production is relatively high due to the adequate climate (Youngquist et al., 1996). These crop species may be an alternative to hardwoods used in paper and paper products (Kamoga et al., 2013). The utilization of these residues is of great importance considering that they are burned or ploughed back into the ground.

Namely, straw as a non-wood raw material is defined as part lignin, part carbohydrate and part extraneous material. Just like in wood materials, straw contains carbohydrate and lignin as two major complex and polymeric chemical components. Lower amounts of extraneous materials, mostly in the form of organic extractives and inorganic minerals (ash), are present in straw as well. It is known that all non-wood materials, if compared against wood materials, consist of the same or lower lignin content. On the other hand, they have in general higher nutrient and silicon content (Hunter, 1988). As cereals are annual plants, their chemical composition is considerably more variable than the chemical composition of wood species. Chemical composition varies not only based on the type and cultivar of cereals but also in respect to the geographic location of cereals, climate and soil conditions (Han, 1998). The proportion of cellulose, hemicelluloses, and lignin in agricultural residue is an important criterion when determining both, its suitability as an economically sustainable raw material and the optimum pathway of its conversion for paper industry. Large quantities of cellulose do not necessarily mean that fibres are appropriate for further processing in paper industry; they are, however, the first of many criteria in the selection of raw materials for further processing.

Numerous researches conducted on a global scale are focused on identifying alternative non-wood raw materials as a source of cellulose fibres. Some types of non-wood fibres have been are already used in some paper grade productions, although the paper quality varies based on the source of the fibres. Wheat straw is considered to be one of the most important agricultural residues based on the reported results. Namely, agro-based fibres are mostly used in the packaging and corrugated cardboard (liner and fluting papers) production (Akbari et al., 2012). It would be beneficial to create the accurate inventory of non-wood fibre sources. The currently accessible data are still incomplete information on availability, suitability, sustainability, storage and cost of agricultural residues. Markets will not be fully open to agricultural fibre sources until the aforementioned data has been properly collected, analysed and applied (Rowel et al., 1998). This research focuses on the chemical composition of wheat, barley and triticale straw as one of the most important indicators of the straw usage in paper production.

\section{MATERIALS AND METHODS}

\section{METODE I MATERIJALI}

\subsection{Straw samples}

2.1. Uzorci slame

The straw used in this research was wheat (lat. Triticum), barley (lat. Hordeum vulgare L.) and triticale (lat. Triticale sp.) crop residues obtained from the continental Croatian fields (Table 1). Namely, cereals chosen for this research provided the highest yield, measured as kilograms per hectare of harvested land, and, consequently, the highest quantity of straw as a harvesting by-product. All used straws are crop residues from winter varieties (cereal sown in October 2011 and harvested in July 2012). Wheat and barley are 
Table 1 Harvested area, yield per hectare and production of crops in year 2011 in Croatia (Croatian Bureau of Statistics) Tablica 1. Požnjevena površina, prinos žitarica po hektaru i proizvodnja zrnja u 2011. godini u Hrvatskoj (Hrvatski zavod za statistiku)

\begin{tabular}{|l|c|c|c|}
\hline $\begin{array}{l}\text { Cereal } \\
\text { Zitarica }\end{array}$ & $\begin{array}{c}\text { Harvested area, ha } \\
\text { Požnjevena površina, } h a\end{array}$ & $\begin{array}{c}\text { Production, } \mathbf{t} \\
\text { Proizvodnja, } t\end{array}$ & $\begin{array}{c}\text { Yield per hectare, } \mathbf{t} \\
\text { Prinos po hektaru, } t\end{array}$ \\
\hline Wheat / pšenica & 149797 & 782499 & 5.20 \\
\hline Maize / kukuruz & 305130 & 1733664 & 5.70 \\
\hline Barley / ječam & 48318 & 193961 & 4.00 \\
\hline Rye / raž & 871 & 2949 & 3.40 \\
\hline Oat / zob & 25344 & 77223 & 3.00 \\
\hline Triticale / pšenoraž & 9951 & 35149 & 3.50 \\
\hline
\end{tabular}

ancient agricultural crops, but triticale (hybrid species of wheat and rye) is a relatively new cereal, the use of which has been gradually increasing in agricultural production.

A week after the harvest season, the collected straws were thoroughly washed to remove any extraneous impurities and dried before use. Straw as a residue of wheat, barley and triticale crops was prepared for the analysis of chemical composition in such a way that stalks (nods and internodes) of each straw were cut into small pieces with a razor blade. Pieces of stalk, 1 $\mathrm{cm}$ long, were small enough for grounding in an analytical mill IKAA10. The material was then placed in a shaker with sieves in order to pass through a mesh sieve of $0.5 \mathrm{~mm}$. However, the mesh sieve was retained on $0.25 \mathrm{~mm}$. These samples were analysed using plant analysis reference procedures by ICP-MS method for elemental analysis and TAPPI standards for organic and inorganic compounds.

\subsection{Chemical characterization}

\subsection{Kemijska svojstva}

Chemical composition of wheat, barley and triticale straw was determined by applying standard isolation methods for major plant chemical components
(Fig. 1). Organic (cellulose, $\alpha$-cellulose, lignin, solvent extractives, moisture) and inorganic compounds were determined according to TAPPI standards.

\subsubsection{Determination of ash ( $w)$}

\subsubsection{Određivanje količine pepela $\left(w_{\text {ash }}\right)$}

A sample was ignited in a muffle furnace at $525^{\circ} \mathrm{C}$ and burnt for 3 hours (TAPPI T211 om-12). For the purpose of ash calculation, a separate sample was analysed for the percentage of moisture by Sartorius moisture analyser. Ash content was calculated as follows:

$$
w_{\text {ash }}=\left(\frac{m_{1}-m_{2}}{m_{\mathrm{u}}}\right) \cdot 100
$$

Where:

$m_{1}$ - weight of moisture-free sample before ignition, $\mathrm{g}$ $m_{2}$ - weight of sample after ignition, $g$ $m_{\mathrm{u}}$ - oven-dry weight of sample, $\mathrm{g}$.

2.2.2 Solvent extractives $\left(w_{\mathrm{SE}}\right)$

2.2.2. Topljive ekstraktivne tvarI $\left(w_{\mathrm{SE}}\right)$

A weight chopped sample was extracted with a mixture of benzene-ethanol $\left(\mathrm{C}_{6} \mathrm{H}_{6}-\mathrm{C}_{2} \mathrm{H}_{5} \mathrm{OH}\right)$ solvent in a ratio of 1:1 for 8 hours in Soxhlet apparatus. The material, extracted in a round bottom flask, was dried

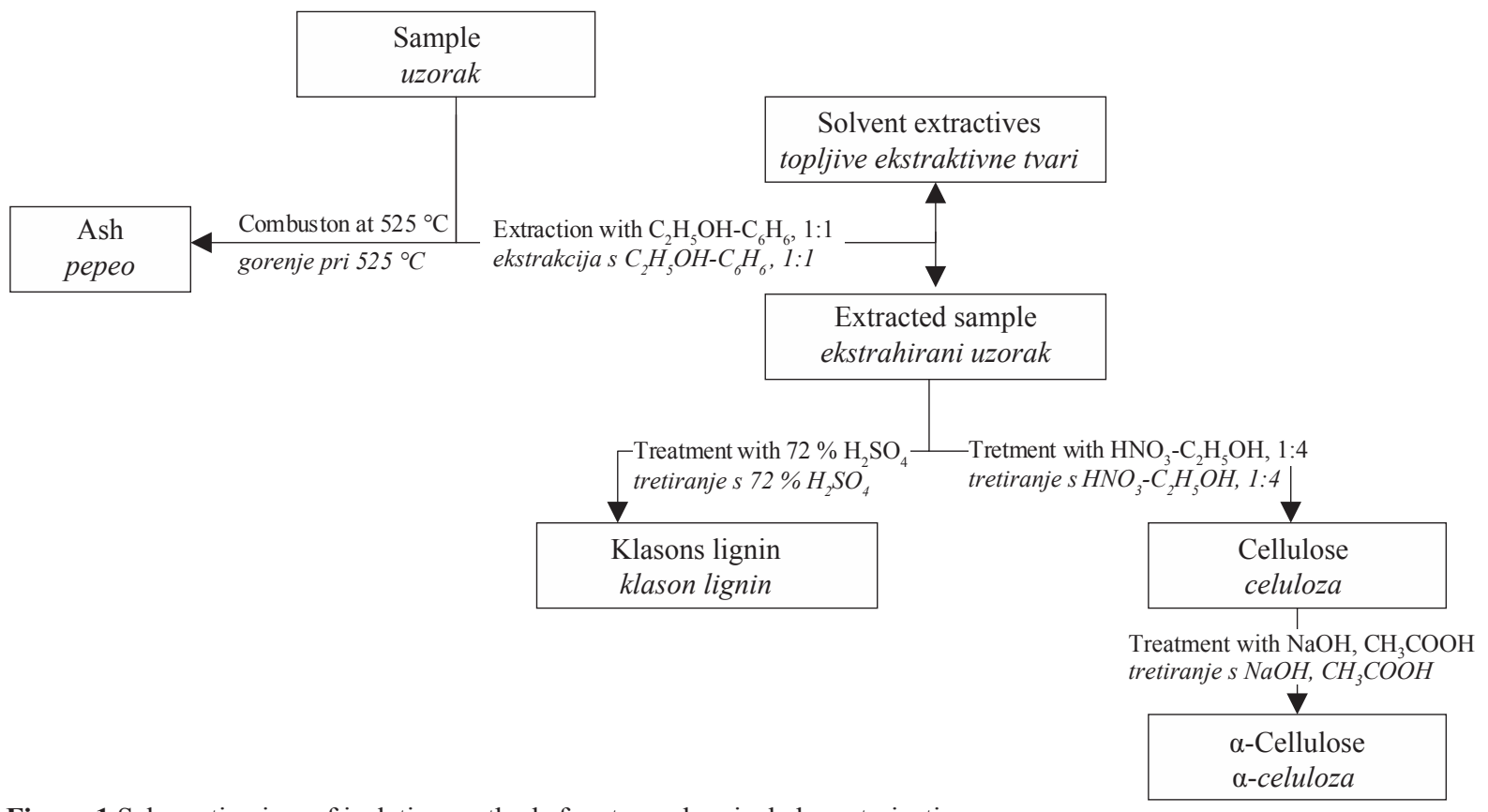

Figure 1 Schematic view of isolation methods for straw chemical characterization

Slika 1. Shematski prikaz izolacijskih metoda za određivanje kemijskog sastava slame 
in an oven at the temperature of $80^{\circ} \mathrm{C}$ to constant weight (TAPPI T204 cm-07). The extracted content was calculated as follows:

Where:

$$
w_{\mathrm{SE}}=\left(\frac{m_{2}-m_{1}}{m_{\mathrm{u}}}\right) \cdot 100
$$

$m_{1}$ - oven-dry weight of flask, $g$

$m_{2}$ - oven-dry weight of extract in flask, $g$

$m_{\mathrm{u}}$ - oven-dry weight of sample, $\mathrm{g}$

\subsubsection{Klasons lignin $\left(w_{\text {lignin }}\right)$
2.2.3. Klason lignin $\left(w_{\text {linn }}\right)$}

The extracted sample, prior to being cooked in distilled water for 4 hours, had been pre-treated by 72 $\%$ sulphuric acid $\left(\mathrm{H}_{2} \mathrm{SO}_{4}\right)$ for 2.5 hours. The solid residue lignin was obtained by filtration and drying in an oven at the temperature of $105^{\circ} \mathrm{C}$ to constant weight (TAPPI T222 om-11). The Klason lignin content was calculated as follows:

Where:

$$
w_{\text {lignin }}=\left(\frac{m_{2}-m_{1}}{m_{\mathrm{u}}}\right) \cdot 100
$$

$m_{1}$ - oven-dry weight of filter paper, $\mathrm{g}$

$m_{2}$ - oven-dry weight of filtrated lignin + weight of filter paper, $g$

$m_{\mathrm{u}}$ - oven-dry weight of sample, $\mathrm{g}$

\subsubsection{Cellulose $\left(w_{\text {cellulgse }}\right)$
2.2.4. Celuloza $\left(w_{\text {cellulose }}\right)$}

Küschner-Hoffer method was used for the determination of cellulose. The extracted sample was cooked in a mixture of nitric acid-ethanol $\left(\mathrm{HNO}_{3}-\right.$ $\mathrm{C}_{2} \mathrm{H}_{5} \mathrm{OH}$ with a ratio of 1:4) in a hot water bath at the temperature of $100^{\circ} \mathrm{C}$. Solid/liquid ratio was $1: 25$. Cooking was done through four extraction cycles until the sludge became completely bleached. Its filtration and drying in an oven at the temperature of $105^{\circ} \mathrm{C}$ to constant weight provided Küschner-Hoffer cellulose, which was calculated as follows:

Where:

$$
w_{\text {cellulose }}=\left(\frac{m_{1}-m_{2}}{m_{\mathrm{u}}}\right) \cdot 100
$$

$m_{1}$ - oven-dry weight of filter paper funnel, $g$

$m_{2}-$ oven-dry weight of funnel + extracted cellulose, $g$ $m_{\mathrm{u}}$ - oven-dry weight of sample, $\mathrm{g}$

2.2.5 $\alpha$-Cellulose ( $\left.w_{\text {a-cellujose }}\right)$

2.2.5. a-celuloza ( $w_{\alpha \text {-cellulose }}$ )

Cellulose extracted from a sample had been obtained through several consecutive extractions with $17.5 \%$ sodium hydroxide $(\mathrm{NaOH})$ solution at $25^{\circ} \mathrm{C}$ and then neutralized with $10 \%$ acetic acid solution $\left(\mathrm{CH}_{3} \mathrm{COOH}\right)$ (TAPPI T203 cm-09). The $\alpha$-cellulose, as an insoluble fraction, was isolated by filtration and drying in an oven at the temperature of $105^{\circ} \mathrm{C}$ to constant weight. The $\alpha$-cellulose content was calculated as follows:

$$
\begin{gathered}
w_{\alpha-\text { cellulose }}=\left(\frac{m_{\alpha \text {-cellulose }} \cdot 10^{4}}{m_{\text {cellulose }} \cdot S}\right) \\
S=100-w_{\text {moisture }}
\end{gathered}
$$

Where:

$m_{\alpha \text {-cellulose }}$ - weight of $\alpha$-cellulose, $g$

$m_{\text {cellulose }}$ - weight of cellulose, $\mathrm{g}$

$S$-weight of moisture-free cellulose sample.

\subsection{Inductively coupled plasma - mass} spectrometry (ICP-MS)

2.3. Spektrometrijska (ICP-MS) masena analiza

The element analysis was performed by applying ICP-MS method. All samples were converted into solution using wet ashing method for organic matter destruction (Campbell et al., 1992; Donohue et al., 1992). This method enabled the detection of macro elements (potassium $(\mathrm{K})$, calcium $(\mathrm{Ca})$, magnesium $(\mathrm{Mg})$, phosphorus $(\mathrm{P})$ ), microelements (boron (B), iron (Fe), copper $(\mathrm{Cu})$, manganese $(\mathrm{Mn})$, molybdenum (Mo), zinc $(\mathrm{Zn})$ ) and metals/metalloids (aluminium (Al), barium (Ba), bismuth $(\mathrm{Bi})$, cadmium $(\mathrm{Cd})$, cobalt $(\mathrm{Co})$, chromium $(\mathrm{Cr})$, mercury $(\mathrm{Hg})$, nickel $(\mathrm{Ni})$, lead $(\mathrm{Pb})$, silicon $(\mathrm{Si})$, vanadium $(\mathrm{V})$ ).

\section{RESULTS}

\section{REZULTATI}

The chemical composition of straw determined by standard isolation methods is presented in Table 2 .

Plant nutrients (macro elements, microelements, metal and metalloids) and ash composition of straw are strongly affected by the type of soil and climate conditions during the growth phase of plant. Table 3 presents the results of ICP-MS analysis of the studied straw.

\section{DISCUSSION}

4. RASPRAVA

The aim of this research was to validate three types of agricultural residues: wheat, barley and triticale as a potential source of raw material in papermaking. Chemical composition of raw materials is the first indication of the possibility of their use in the process of cellulose fibre isolation. From the paper industry's

Table 2 Chemical composition of analysed straw

Tablica 2. Kemijski sastav analizirane slame

\begin{tabular}{|l|c|c|c|}
\hline $\boldsymbol{w}, \boldsymbol{\%}$ & Wheat / Pšenica & Barley / Ječam & Triticale / P̌̌enoraž \\
\hline Moisture / Sadržaj vode & $6.94 \pm 0.97$ & $6.62 \pm 0.70$ & $7.73 \pm 0.82$ \\
\hline Ash 525 ${ }^{\circ}$ C / Pepeo & $9.27 \pm 0.33$ & $7.14 \pm 0.14$ & $5.27 \pm 0.16$ \\
\hline Solvent extractives / Topljive ekstraktivne tvari & $3.00 \pm 0.57$ & $2.61 \pm 0.28$ & $3.02 \pm 0.42$ \\
\hline Klason lignin / Klason lignin & $24.66 \pm 1.63$ & $21.71 \pm 1.17$ & $12.59 \pm 1.77$ \\
\hline Küschner-Hoffer cellulose / Celuloza & $48.28 \pm 1.01$ & $45.89 \pm 0.72$ & $52.88 \pm 0.49$ \\
\hline$\alpha$-cellulose / $\alpha$-cellulose & 31.47 & 37.97 & 44.22 \\
\hline
\end{tabular}


Table 3 Nutrients in analysed straw

Tablica 3. Elementi sadržani u analiziranoj slami

\begin{tabular}{|c|c|c|c|}
\hline \multirow{2}{*}{$\begin{array}{c}\text { Nutrient } \\
\text { Element }\end{array}$} & $\begin{array}{c}\text { Wheat } \\
\text { P̌̌enica }\end{array}$ & $\begin{array}{c}\text { Barley } \\
\text { Ječam }\end{array}$ & $\begin{array}{c}\text { Triticale } \\
\text { Pšenoraž }\end{array}$ \\
\cline { 2 - 4 } & \multicolumn{3}{|c|}{$\mathrm{mg} / \mathrm{kg}$} \\
\hline $\mathrm{K}$ & 10340.50 & 5014.50 & 13975.50 \\
\hline $\mathrm{Ca}$ & 3300.00 & 3627.50 & 2769.00 \\
\hline $\mathrm{Mg}$ & 1051.00 & 656.50 & 897.50 \\
\hline $\mathrm{P}$ & 595.00 & 1303.00 & 479.50 \\
\hline $\mathrm{Zn}$ & 53.69 & 181.39 & 22.78 \\
\hline $\mathrm{Fe}$ & 47.04 & 101.68 & 36.52 \\
\hline $\mathrm{Mn}$ & 30.74 & 1.43 & 72.97 \\
\hline $\mathrm{Cu}$ & 3.78 & 90.88 & 8.14 \\
\hline $\mathrm{B}$ & 3.55 & 101.67 & 0.00 \\
\hline $\mathrm{Mo}$ & 0.99 & 0.40 & 0.05 \\
\hline $\mathrm{Al}$ & 193.24 & 160.53 & 31.80 \\
\hline $\mathrm{Bi}$ & 117.62 & 149.41 & 201.72 \\
\hline $\mathrm{Si}$ & 71.08 & 147.98 & 7.74 \\
\hline $\mathrm{Ba}$ & 42.01 & 2.81 & 53.03 \\
\hline $\mathrm{Cr}$ & 3.68 & 12.62 & 2.66 \\
\hline $\mathrm{Pb}$ & 1.76 & 26.63 & 2.91 \\
\hline $\mathrm{Ni}$ & 1.57 & 4.77 & 2.37 \\
\hline $\mathrm{Cd}$ & 0.15 & 0.55 & 0.11 \\
\hline $\mathrm{Co}$ & 0.03 & 0.12 & 0.03 \\
\hline $\mathrm{V}$ & 0.00 & 65.95 & 0.81 \\
\hline $\mathrm{Hg}$ & 0.00 & 0.00 & 0.00 \\
\hline & & & \\
\hline
\end{tabular}

perspective, it is preferred that the plant material contains cellulose in the highest share possible and that the minimum share of other accompanying non-cellulose components is kept to a minimum.

Chemical characteristics of the straw as a raw material for cellulose fibres are important for producing pulp of high chemical purity and high $\alpha$-cellulose content. The amounts of cellulose (especially $\alpha$-cellulose) and lignin content in the selected raw materials are the most important indicators of use of raw materials in paper production. In general, the higher the lignin content, the lower is the cellulose content (Han, 1998). It is known that the content of organic and inorganic components depends not only on plant species, but also on botanical classification, stalk height, farming conditions such as climate, soil and human influence on the growing phase of plants (McKean et al., 1997). In case of wood species these chemical composition variations also exist but they are not as high as in annual plants. For instance, beech wood that was sampled in different locations with various soil type and phytocoenoses, the statistically significant differences were found in the solvent extractives and cellulose content, while the difference in ash, lignin and wood polyoses content were negligible [Antonović et al. 2007]. Therefore, it could be concluded that non-wood fibrous raw materials have more variations in chemical composition for the same species than wood (Hunter, 1988). The analysis presented in this research showed that present amounts of cellulose, lignin and solvent extractives (Table 2) were similar to those encountered in softwood and hardwood (Rowell et al., 2005). Cellulose obtained by Küschner-Hoffer method was relatively high in all-analysed straw: barley $(45.89 \pm 0.72)$
$\%$, wheat $(48.28 \pm 1.01) \%$ and triticale $(52.88 \pm 0.49)$ $\%$, which makes these cereals interesting raw materials for pulp and paper industry. Lignin content was significantly low in triticale straw $(12.59 \pm 1.77) \%$, while it was much higher in two other straws: barley $(21.71 \pm$ $1.17) \%$ and wheat $(24.66 \pm 1.63) \%$. As expected, ash content determined at $525{ }^{\circ} \mathrm{C}$ was relatively high in all analysed straws, considering that it is a distinguishing quality for all non-wood raw materials. Wheat straw had the highest ash content $(9.27 \pm 0.33) \%$, which could be considered as a serious disadvantage in the pulping and papermaking context. Barley straw has somewhat lower ash content $(7.14 \pm 0.14) \%$ and the triticale straw had the lowest ash content $(5.27 \pm 0.16)$ $\%$. The issue of potentially high ash content in straw could be easily solved by fractionating, that is, singling out the components with less desirable properties, such as leaves and nodes (pre-treatment), which will have a positive effect on the ash content, and eventually the pulp and paper properties (McKean et al., 1997). According to complete chemical composition presented in Table 2, it is clearly noticeable that triticale straw contains the highest amount of cellulose $(52.88 \pm 0.49)$ $\%$ and at the same time the lowest amount of non-cellulose components, especially lignin $(12.59 \pm 1.77) \%$ and ash $(5.27 \pm 0.16) \%$.

As previously noted, low mineral content in the plant material is preferred in fibre production (Saijonkari-Pahkala, 2001). By ICP-MS analysis in all straw samples, $\mathrm{K}$ was determined in a notably higher concentration than other macro elements (Table 3). That is in correlation with the results obtained in other researches of wheat (Antongiovanni et al., 1991; Rousu et al., 2002; McKean et al., 1997) and barley (Antongiovanni et al., 1991). The highest concentration of $\mathrm{K}$ was observed in triticale straw. High concentration of K was characteristic of all cereal straw. Macro elements in all-analysed straws followed the sequence $\mathrm{K}>\mathrm{Ca}>\mathrm{Mg}>\mathrm{P}$.

The amounts of some nutrients in straw have negative impacts on facilities equipment used during the raw material conversion to pulp ( $\mathrm{Si})$ and some $(\mathrm{Cu}, \mathrm{Fe}$, $\mathrm{Co}, \mathrm{Mn}, \mathrm{Pb}$ and $\mathrm{Zn}$ ) on the optic and quality of paper as a final product of paper production (Saijonkari-Pahkala, 2001). These metals may be added to the paper from the fibre source (straw), which may contain trace elements from the ground in which it was grown, or by the equipment, water and chemicals used in the paper manufacturing process. Their presence can cause disadvantageous changes in paper as it ages and is exposed to mould, high relative humidity, light, and pollution or/ and some conservation treatments (e.g., oxidative and reduction bleaching) (Leponiemi et al., 2010; Sridach, 2010; McKean et al., 1997). From all nutrients, $\mathrm{Si}$ is the most damaging element in the raw material for pulping, because it complicates the recovery of chemicals, wears out the installations of paper factories and can affect the paper quality (Saijonkari-Pahkala, 2001; Gonzalez et al., 2008; Sotannde et al., 2014 ). According to gained results of straw chemical composition analysis (Table 3 ), it could be concluded that barley straw contains the 
highest concentration of all analysed microelements. These microelements are present in wheat straw in a significantly lower concentration, while their concentration is the lowest in triticale straw. This trend does not pertain only to Mn concentration, as this microelement has been determined to have the highest concentration in triticale straw. The results of $\mathrm{Si}$ concentration in triticale straw indicate that this cereal contains significantly less silicon than the other two analysed straw crops (Table 3). The concentrations of all analysed nutrients in wheat, barley and triticale straws (Table 3) are in correlation with those reported by Koppejan (Koppejan et al., 2008). It was confirmed that the concentration of $\mathrm{Si}$ in barley straw is high. The amount of undesirable minerals in a pulping process can be minimised by choosing a suitable straw as the raw material for pulping based on its chemical composition.

\section{CONCLUSION \\ 5. ZAKLJUČAK}

Chemical composition of three alternative sources of fibres was determined. According to the obtained results, it was evident that straw as non-wood plant material has nearly the same cellulose content as most wood spices, lower content of lignin and higher amount of ash and solvent extractives. Conducted chemical component analysis showed that wheat, barley and triticale straw contain a high amount of cellulose, which justifies their valorisation as a source of fibres in papermaking industry. All obtained results indicated that triticale straw contains the highest amount of cellulose (and $\alpha$-cellulose) and has, at the same time, the lowest lignin and ash content. Undesirable minerals in a pulping process are present in a low content in triticale straw. It could be concluded from the chemical point of view, that triticale represents the type of fibre source that can bring competitiveness and vitality to paper industry as an alternative non-wood raw material.

Knowledge of the composition of raw materials and their variations due to agro-climatic conditions of growth is essential in the chemical treatment to extracted cellulose fibres. For obtaining a quality pulp from straw, it is important to use the proper method for fibre isolation in order to avoid the loss of cellulose content during the separation of non cellulose components from the lignocellulose structure of straw. It is important to point out that the chemical composition of raw materials is the first indication of their potential use in cellulose fibre isolation. However, physical, chemical and morphological characteristics of isolated fibres also have a great impact on the pulp production and consequently on paper properties. Therefore, further research will be devoted to fibre isolation and to finding out which isolation process could provide the highest quality fibres based on their physical, chemical and morphological properties.

\section{Acknowledgements - Zahvale}

This research was performed within the project „Cereal straw as a source of fibres in the newsprint production" supported by the University of Zagreb.

\section{REFERENCES}

\section{LITERATURA}

1. Akbari, M.; Resalati, H., 2012: Use of agricultural waste in the pulp and paper industry. Proceeding of the 1th International and The $4^{\text {th }}$ National Congress on Recycling of Organic Waste in Agriculture, Iran, p. 4.

2. Antongiovanni, M.; Sargentini, C., 1991: Variability in chemical composition of straws. Options Méditerranéennes - CHIEAM, 49-53.

3. Antonović, A.; Jambreković, V.; Pervan, S.; Ištvanić, J.; Moro, M.; Zule, J., 2007: Utjecaj lokaliteta uzorkovanja na grupni kemijski sastav bijeli bukovine (Fagus sylvati$c a$ L.). Drvna industrija, 58 (3): 119-125.

4. Campbell, C. R.; Plank, C. O., 1992: Sample preparation. Plant analysis reference procedures for the southern region of the United States. The University of Georgia, editor C. O. Plank, p. 7.

5. Chandra, M., 1998: Use of nonwood plant fibers for pulp and paper industry in Asia: potential in China, p. 84.

6. De Galembert, B., 2003: Wood Supply for the growing European pulp and paper industry. Seminar on Strategies for the Sound Use of Wood. Economic Commission for Europe/Food and Agriculture Organization, Romania, p.8.

7. Donohue, S. J.; Aho, D. W., 1992: Determination of P, K, $\mathrm{Ca}, \mathrm{Mg}, \mathrm{Mn}, \mathrm{Fe}, \mathrm{Al}, \mathrm{B}, \mathrm{Cu}$, and $\mathrm{Zn}$ in Plant Tissue by Inductively Coupled Plasma (ICP) Emission Spectroscopy. Plant analysis reference procedures for the southern region of the United States. The University of Georgia, editor C.O. Plank, p. 34.

8. Gonzalez, M.; Canton, L.; Rodriguez, A.; Labidi, J., 2008: Effect of organosolv and soda pulping processes on the metals content of non-woody pulps. Bioresour. Technol., 99: 6621-6625.

http://dx.doi.org/10.1016/j.biortech.2007.12.038.

9. Han, J. S., 1998: Properties of nonwood fibres. Proceedings of the Korean society of wood science and technology annual meeting, p. 12 .

10. Hurter, A. M., 1988: Utilization of annual plants and agricultural residues for the production of pulp and paper. Proceeding of TAPPI Pulping Conference 1988. New Orleans, LA, Book 1, TAPPI Press, Atlanta, GA, p.p. 139-160.

11. Jahan, M. S.; Gunter, B. G.; Rahman, A. F. M. A., 2009: Substituting Wood with Nonwood Fibers in Papermaking: A Win-Win Solution for Bangladesh. BDRWPS Working Paper No. 4, p.15. Available at SSRN: http://dx.doi.org/10.2139/ssrn.1322292.

12. Kamoga, O. L. M.; Byaruhanga, J. K.; Kirabira, J. B., 2013: A Review on Pulp Manufacture from Non Wood Plant Materials. International Journal of Chemical Engineering and Applications, 4 (3): 144-148. http://dx.doi.org/10.7763/IJCEA.2013.V4.281.

13. Koppejan, J.; Van Loo, S., 2008: The Handbook of Biomass Combustion and Co-firing, p. 464.

14. Lainio, U., 2001: Natural and synthetic fibres improving tensile strength and elongation of paper products, Master's thesis, p. 84. Available at SSRN: http://www.doria. fi/bitstream/handle/10024/63333/nbnfi-e201008112300. pdf? sequence $=3$

15. Leponiemi, A.; Johansson, A.; Edelmann, K.; Sipilä, K., 2010: Producing pulp and energy from wheat straw. Appita Journal, 63 (1): 65-73.

16. Leponiemi, A., 2008: Non-wood pulping possibilities - a challenge for the chemical pulping industry. Appita Journal, 61 (3): 234-243.

17. McKean, W. T.; Jacobs, R. S., 1997: Wheat straw as a paper fiber source. Clean Washington Center, 1-55. 
18. Rousu, P.; Rousu, P.; Anttila, J., 2002: Sustainable pulp production from agricultural waste. Resources, Conservation and Recycling, 35: 85-103. http://dx.doi.org/10.1016/S0921-3449(01)00124-0.

19. Rowell, R. M.; Pettersen, R.; Han, J. S.; Tshabalala, M. A., 2005: Cell wall chemistry. Handbook of wood chemistry and wood composites, edited by Rowell R. M., USA, 43-84.

20. Rowell, R. M.; Cook, C., 1998: Types and amounts of nonwood fibers available in the USA. 1998 TAPPI Proceedings North American Nonwood Fiber Symposium, Atlanta, Georgia, p. 6.

21. Saijonkari-Pahkala, K., 2001: Non-wood plants as raw material for pulp and paper. Agricultural and Food Science in Finland, p.101.

22. Sotannde, O. A.; Oluwadare, A. O., 2014: Fibre and Elemental Contents of Thaumatococcus daniellii Stalk and its Implications as Non-Wood Fibre Source. International Journal of Applied Science and Technology, 4 (1): 178-185.

23. Sridach, W., 2010: The environmentally benign pulping process of non-wood fibers. Suranaree Journal of Science \& Technology, 17 (2): 105-123.
24. Valois, M.; Akim, E.; Lombard, B.; Parik, T., 2012: Chapter 8. Paper, paperboard and woodpulp markets 2011-2012. UNECE/FAO Forest Products Annual Market Review 2011-2012, 79-94., https://www.unece.org/ fileadmin/DAM/timber/publications/08.pdf.

25. Youngquist, J. A.; Krzysik, A. M.; English, B. W.; Spelter, H. N.; Chow, P., 1996: Agricultural Fibers for Use in Building Components. The use of recycled wood and paper in building applications: Proceedings of a 1996 symposium, 123-134.

\section{Corresponding address:}

\section{Assistant IVANA PLAZONIĆ}

University of Zagreb

Faculty of Graphic Arts

Getaldićeva 2

10000 Zagreb, CROATIA

e-mail: ivana.plazonic@grf.hr 